Geochimica et Cosmochimica Acta 70 (2006) 918-930

\title{
Methylmercury Cycling in Sediments on the Continental Shelf of Southern New England
}

Chad R. Hammerschmidt*, William F. Fitzgerald

Department of Marine Sciences, University of Connecticut, Groton, CT 06340

*Corresponding author. Present address: Department of Marine Chemistry \& Geochemistry, Woods Hole Oceanographic Institution, Woods Hole, MA 02543, USA.

E-mail address: methylhg@whoi.edu (C. R. Hammerschmidt) 


\section{Abstract}

Exposure of humans to monomethylmercury (MMHg) occurs primarily through consumption of marine fish, yet there is limited understanding concerning the bioaccumulation and biogeochemistry of MMHg in the biologically productive coastal ocean. We examined the cycling of MMHg in sediments at three locations on the continental shelf of southern New England in September 2003. MMHg in surface sediments is related positively to inorganic Hg $(\mathrm{Hg}(\mathrm{II})=$ total $\mathrm{Hg}-\mathrm{MMHg})$, the geographical distribution of which is influenced by organic material. Organic matter also largely controls the sediment-water partitioning of Hg species and governs the availability of dissolved $\mathrm{Hg}(\mathrm{II})$ for methylation. Potential gross rates of MMHg production, assayed by experimental addition of ${ }^{200} \mathrm{Hg}$ to intact sediment cores, are correlated inversely with the distribution coefficient $\left(K_{\mathrm{D}}\right)$ of $\mathrm{Hg}(\mathrm{II})$ and positively with the concentration of $\mathrm{Hg}(\mathrm{II})$, most probably as $\mathrm{HgS}^{0}$, in $0.2-\mu \mathrm{m}$ filtered pore water of these low-sulfide deposits. Moreover, the efflux of dissolved MMHg to overlying water (i.e., net production at steady state) is correlated with the gross potential rate of MMHg production in surface sediments. These results suggest that the production and efflux of MMHg from coastal marine sediments is limited by $\mathrm{Hg}(\mathrm{II})$, loadings of which presumably are principally from atmospheric deposition to this region of the continental shelf. The estimated diffusive flux of MMHg from the shelf sediments averages 9 pmol m $\mathrm{m}^{-2} \mathrm{~d}^{-1}$. This flux is comparable to that required to sustain the current rate of MMHg accumulation by marine fish, and may be enhanced by the efflux of MMHg from nearshore deposits contaminated more substantially with anthropogenic Hg. Hence, production and subsequent mobilization of MMHg from sediments in the coastal zone may be a major source of MMHg to the ocean and marine biota, including fishes consumed by humans. 


\section{Introduction}

Humans are exposed to monomethylmercury (MMHg) principally by the consumption of fish (Fitzgerald and Clarkson, 1991), most (> 60\%) of which are from marine systems (U.S. EPA, 2002). Moreover, the coastal zone supports greater than $75 \%$ of marine fish productivity (Ryther, 1969). This means that the biogeochemistry and bioaccumulation of MMHg in nearshore and continental shelf areas may be major factors affecting the exposure of humans to MMHg. However, and unfortunately, little is known about the production and cycling of MMHg in coastal marine systems and the open ocean, where most of the MMHg in biota has been hypothesized to result from production in deep sea sediments and/or hydrothermal systems (Kraepiel et al., 2003).

We have investigated the biogeochemistry (Hammerschmidt and Fitzgerald, 2004; Hammerschmidt et al., 2004; Balcom et al., 2004) and bioaccumulation (Hammerschmidt, 2005) of MMHg in Long Island Sound (LIS), a large and biologically productive coastal embayment in the northeastern United States. These studies have shown that (1) sedimentary production of MMHg is influenced strongly by the availability of dissolved (i.e., $<0.2 \mu \mathrm{m}$ ) inorganic Hg, most likely as $\mathrm{HgS}^{0}$, to methylating bacteria, (2) partitioning with sedimentary organic matter largely controls pore water concentrations of inorganic $\mathrm{Hg}$, (3) bioturbation can enhance $\mathrm{Hg}$ methylation, (4) in situ benthic production is the principal source of MMHg to the Sound, and (5) most of the MMHg in lower trophic levels of LIS can be attributed to production and mobilization from underlying sediments. Also, the results from LIS suggest that the diffusive efflux of MMHg from sediments on the continental shelf would approach that required to account for its accumulation in near-shore and pelagic fish (Hammerschmidt et al., 2004). 
We tested this hypothesis and examined sedimentary cycling of MMHg in sediments at three locations on the continental shelf of southern New England. The sampling locations were selected to span ranges in water depth and sedimentary characteristics (e.g., organic matter, total Hg) that are typical of other shelf deposits. Here, we show that the processes and mechanisms affecting the cycling of MMHg in sediments on the continental shelf are comparable to those in the sedimentary environs of LIS. Thus, and most importantly, organic matter, through its control of inorganic $\mathrm{Hg}$ in pore water, is a major influence on the production and distribution of $\mathrm{MMHg}$ in low-sulfide coastal marine sediments. Further, this study suggests that deposits on the continental shelf are a potentially significant source of MMHg to oceanic systems, including fishes for human consumption.

\section{Materials and methods}

\subsection{Sampling}

Sediments were collected with a box corer $\left(0.06 \mathrm{~m}^{2}\right.$, Ocean Instruments, San Diego, CA) from three stations (71north, 71central, and 71south) on the continental shelf of southern New England, northwestern Atlantic Ocean, on September 24-25, 2003 (Fig. 1). The sampling locations were selected to span ranges in both water depth and sediment grain size, which had been surveyed previously (Twitchell et al., 1981). Grain size of coastal marine deposits often is correlated with organic matter and inorganic Hg (e.g., Varekamp et al., 2000), factors that can affect the biogeochemistry of MMHg (Hammerschmidt and Fitzgerald, 2004). Fine-grained material ( $\leq 63 \mu \mathrm{m}$; silt + clay) comprised about $20 \%$ of the sediment mass at station 71 north, $98 \%$ at 71 central, and $50 \%$ at 71 south. Collection of intact sediment cores with overlying water 
from sandy environs, such as station 71north, is challenging and can be aided by applying additional lead weight to the box corer and allowing it to free fall through the water column. Water depths at our sampling locations were $59 \mathrm{~m}$ (71north), $81 \mathrm{~m}$ (71central), and $131 \mathrm{~m}$ (71south). Sediments were sampled in September, when the temperature of water and sediment was near its seasonal maximum, because rates of $\mathrm{Hg}$ methylation increase with temperature (Winfrey and Rudd, 1990; Hammerschmidt and Fitzgerald, 2004). The temperature of water overlying sediments at these locations was about $21^{\circ} \mathrm{C}$ at 71 north and about $12{ }^{\circ} \mathrm{C}$ at stations 71central and 71south. Bottom water salinity was comparable among sites, ranging from 33.6 at station 71north to 34.4 at 71south. In addition to sediment, surface water (1 m depth) and water below the seasonal thermocline (30 m) were sampled at each station for analysis of dissolved (< $0.2 \mu \mathrm{m}$ filtered) and particulate MMHg ( $>0.2 \mu \mathrm{m})$. Water samples were collected at each station with a Teflon coated Go-Flo ${ }^{\mathrm{TM}}$ bottle suspended from a Kevlar line prior to sediment sampling. MMHg was not measured in water collected with the box corer.

Nine cylindrical, intact sub-cores of sediment were sampled from two box-cores taken at each station. Box-cored sediments and overlying water were subsampled with polycarbonate tubes (6.4 cm inner diameter). Four sub-cores were collected from the first box of sediment and overlying water; one was used for $\mathrm{Hg}$ speciation in both the solid and pore water phases, another for the determination of acid-volatile sulfide (AVS), grain size, and dissolved sulfide and oxygen, and the other two were used for assays of $\mathrm{Hg}$ methylation potentials with an isotopic tracer $\left({ }^{200} \mathrm{Hg}\right)$. Five sub-cores were collected from the second box of sediment; two were used for $\mathrm{Hg}$ speciation in surface sediment only (upper $3 \mathrm{~cm}$ ), and the other three for analysis of benthic macrofauna. Macrofauna cores were sieved through a 300- $\mu \mathrm{m}$ mesh screen within $12 \mathrm{~h}$ 
of collection, and the retained material was preserved with $70 \%$ ethanol until identification and enumeration of the organisms. Sediment cores for chemical analysis were stored in the dark at 5 ${ }^{\circ} \mathrm{C}$ until sectioning. Cores for the determination of ${ }^{200} \mathrm{Hg}$ methylation potentials from station 71north were kept at $22 \pm 1{ }^{\circ} \mathrm{C}$ both prior to and during incubations in darkened containers on the deck of the research vessel, and those from stations 71central and 71south were incubated similarly, but at $14 \pm 3{ }^{\circ} \mathrm{C}$.

Sediment cores for chemical analyses were sectioned within 4-8 h of collection (Hammerschmidt et al., 2004). Cores were placed inside a low- $\mathrm{O}_{2}$ (evacuated, $\mathrm{N}_{2}-$ flushed) glovebox before overlying water was removed carefully with a syringe. Sediments were sectioned with plastic tools in 1-cm vertical intervals. Pore waters were extracted from sediments by centrifugation and vacuum filtration of the supernatant through $0.2-\mu \mathrm{m}$ polycarbonate filters inside the glovebox (Mason et al., 1998). Acid-cleaned filters were rinsed with deoxygenated reagent-grade water (nominal resistivity, $18.2 \mathrm{M} \Omega-\mathrm{cm}$ ) immediately prior to sample filtration. Filtered pore water, containing both dissolved and colloidal size fractions, was acidified to about $0.5 \%$ with $\mathrm{HCl}$ and stored frozen $\left(\leq-20^{\circ} \mathrm{C}\right)$ until analysis. Sediments were frozen promptly after removal from the glovebox.

\subsection{Hg Methylation potentials}

Gross potential rates of MMHg production were assayed by adding isotopically enriched ${ }^{200} \mathrm{Hg}$ (96.41\% ${ }^{200} \mathrm{Hg}$; Oak Ridge National Laboratory) to two intact sediment cores from each station. Our methods for spike preparation, sediment incubation, MMHg extraction, and isotopic Hg analysis by inductively coupled plasma mass spectrometry (ICPMS) are detailed in 
Hammerschmidt and Fitzgerald (2004). Briefly, a stock solution of enriched ${ }^{200} \mathrm{Hg}\left(\mathrm{NO}_{3}\right)_{2}$ was diluted with water overlying the sediments, and ${ }^{200} \mathrm{Hg}^{2+}$ was allowed to react with natural ligands for 1-2 $\mathrm{h}$ before aliquots of the dilution were added to sediment cores in 1-cm vertical increments by injection through silicone septa. Added ${ }^{200} \mathrm{Hg}$ increased the ambient $\mathrm{Hg}$ burden in sediments $8-12 \%$. The relative degree of enrichment with ${ }^{200} \mathrm{Hg}$ was greater than that used in a similar assessment of LIS sediments, which have about 10-fold more ambient $\mathrm{Hg}$ (Hammerschmidt et al., 2004), but it was necessary to ensure that a quantifiable amount of $\mathrm{CH}_{3}{ }^{200} \mathrm{Hg}$ was produced. Measured rates of ${ }^{200} \mathrm{Hg}$ methylation are considered methylation potentials because the added $\mathrm{Hg}$, having undetermined chemical speciation and sediment-water partitioning, may be more available for methylation than ambient inorganic $\mathrm{Hg}$ (Benoit et al., 2003). Cores were incubated for $6 \mathrm{~h}$ in the dark at in situ temperatures before termination by sectioning of the cores and freezing the sediment sections. A 6-h incubation period was used to minimize potential in situ demethylation of $\mathrm{CH}_{3}{ }^{200} \mathrm{Hg}$ product. MMHg was extracted from lyophilized, incubated sediments with acid and $\mathrm{CH}_{2} \mathrm{Cl}_{2}$ (Bloom et al., 1997; Hammerschmidt and Fitzgerald, 2004), and the fraction of added ${ }^{200} \mathrm{Hg}$ transformed to $\mathrm{CH}_{3}{ }^{200} \mathrm{Hg}$ was measured by continuous-flow cold vapor generation with a Finnigan Element2 magnetic sector ICPMS (Klaue and Blum, 1999; Hammerschmidt and Fitzgerald, 2004). Methylation of added ${ }^{200} \mathrm{Hg}$ was quantified as the excess concentration of ${ }^{200} \mathrm{Hg}$ versus ${ }^{202} \mathrm{Hg}$ in sample extracts (Hintelmann and Evans, 1997). The method detection limit (MDL) of these analyses is a function of ambient MMHg concentration, natural abundance of ${ }^{200} \mathrm{Hg}(23.13 \%)$, and precision of our ${ }^{200} \mathrm{Hg} /{ }^{202} \mathrm{Hg}$ ratio measurements (Hintelmann and Evans, 1997), which averaged 0.93\% relative standard 
deviation (RSD) for 11 independent analyses of internal MMHg standards. The average MDL for our analyses corresponds to a ${ }^{200} \mathrm{Hg}$ methylation potential of about $0.2 \% \mathrm{~d}^{-1}$.

${ }^{200} \mathrm{Hg}$ methylation potentials were corrected for "carry-over" of $\mathrm{Hg}^{2+}$ in the $\mathrm{CH}_{2} \mathrm{Cl}_{2}$ phase during extraction (Hammerschmidt and Fitzgerald, 2004). In natural waters and in our extraction procedure, $\mathrm{Hg}^{2+}$ can form complexes that make it relatively hydrophobic (e.g., Hg-organic, $\mathrm{HgS}^{0}, \mathrm{HgCl}_{2}{ }^{0}$ ) and soluble in the $\mathrm{CH}_{2} \mathrm{Cl}_{2}$ phase of our extraction. Such “carryover” Hg is interpreted as MMHg by our methodology, which assumes that all Hg partitioning into $\mathrm{CH}_{2} \mathrm{Cl}_{2}$ is $\mathrm{MMHg}$. We accounted for the potential transfer of ${ }^{200} \mathrm{Hg}^{2+}$ by adding ${ }^{201} \mathrm{Hg}\left(\mathrm{NO}_{3}\right)_{2}$ (Oak Ridge National Laboratory, 98.11\% ${ }^{201} \mathrm{Hg}$ ) to lyophilized sediments before extraction (about $25 \%$ of total samples analyzed). The amount of ${ }^{201} \mathrm{Hg}$ added was comparable to the quantity of ${ }^{200} \mathrm{Hg}$ added to whole sediment prior to incubation. Transfer of added ${ }^{201} \mathrm{Hg}^{2+}$ to analytical extracts was evaluated as the excess concentration of ${ }^{201} \mathrm{Hg}$ versus ${ }^{202} \mathrm{Hg}$ (Hintelmann and Evans, 1997). Carry-over of ${ }^{201} \mathrm{Hg}^{2+}$ averaged 0.15\% (1 SD, 0.07\%; $n=15$ ) of the nominal mass added prior to extraction. This fraction was comparable to the amount of ${ }^{201} \mathrm{Hg}^{2+}$ carried over in LIS sediments extracts (mean, 0.12\%; $1 \mathrm{SD}, 0.03 \% ; n=12$; Hammerschmidt and Fitzgerald, 2004). We corrected the measured quantity of $\mathrm{CH}_{3}{ }^{200} \mathrm{Hg}$ for 0.15\% transfer of ${ }^{200} \mathrm{Hg}^{2+}$ added for the incubation assay. Although ambient $\mathrm{Hg}^{2+}$ also was carried over during the acid/ $\mathrm{CH}_{2} \mathrm{Cl}_{2}$ extraction, it has no effect on our determination of ${ }^{200} \mathrm{Hg}$ methylation potentials, assuming that ambient $\mathrm{Hg}$ in the shelf sediments has natural isotopic abundance and that individual isotopes are transferred in proportion to their atomic mass fraction. 
Sediment sections from at least one whole core from each site were analyzed for ${ }^{200} \mathrm{Hg}$

methylation. The precision (relative percent difference, RPD) of ${ }^{200} \mathrm{Hg}$ methylation potential measurements averaged 20\% $(n=13)$, based on analyses of methodically replicated subsamples. Additional sections from a second core were selected randomly for analysis. Agreement between samples from the same depth of the two cores is shown by the error bars $( \pm 1 \mathrm{SE})$ in Figure 10.

\subsection{Determination of $\mathrm{Hg}$ species}

Total Hg and MMHg were measured in 0.2- $\mu \mathrm{m}$ filtered pore waters and lyophilized sediments. Total Hg and MMHg in the solid phase of sediment were defined operationally as the fraction of each species remaining after pore water removal. Total Hg in pore water was quantified by dual Au-amalgamation cold vapor atomic fluorescence spectrometry (CVAFS; Fitzgerald and Gill, 1979; Bloom and Fitzgerald, 1988) after acid digestion and BrCl oxidation of the samples (Hammerschmidt and Fitzgerald, 2004). Total Hg in the solid phase was quantified with a Milestone DMA-80 pyrolytic Hg analyzer. MMHg was extracted from sediment and pore water by aqueous distillation (Hammerschmidt and Fitzgerald, 2001) and measured with flow-injection gas chromatographic CVAFS (Bloom, 1989; Tseng et al., 2004). We define the difference between total Hg and MMHg in pore water and solid phases as Hg(II). Thus, $\mathrm{Hg}(\mathrm{II})$ represents the sum of all $\mathrm{Hg}^{2+}$ species that are complexed with inorganic and organic ligands.

MMHg was measured in filtered seawater after quantitative extraction with $\mathrm{CH}_{2} \mathrm{Cl}_{2}$. Seawater samples were filtered through $0.2-\mu \mathrm{m}$ pore size polycarbonate membranes within $6 \mathrm{~h}$ 
of sampling, and the filtrate was frozen promptly without chemical preservative. The filters also were stored frozen, and were analyzed for particulate $\mathrm{MMHg}$ after leaching with dilute $\mathrm{HNO}_{3}$ (Hammerschmidt and Fitzgerald, 2005). Frozen samples of filtered seawater were thawed overnight in the laboratory, and $200 \mathrm{~mL}$ were transferred to a 250 -mL Teflon bottle (extraction bottle). Ten $\mathrm{mL}$ of $\mathrm{CH}_{2} \mathrm{Cl}_{2}$ were added to seawater in the extraction bottle, and it was capped and shaken vigorously by hand for $12 \mathrm{~min}$. $\mathrm{CH}_{2} \mathrm{Cl}_{2}$ extracts $\mathrm{MMHg}$, most likely as a hydrophobic organo- or chloro-complex, by solubility from the polar seawater matrix, which contains potential analytical interferences (e.g., $\mathrm{Cl}^{-}$). After shaking, the organic phase containing sample MMHg was transferred to a different bottle (back-extraction bottle) containing $100 \mathrm{~mL}$ of reagent-grade water. MMHg was extracted from each seawater sample twice more with the same method, resulting in $30 \mathrm{~mL}$ of $\mathrm{CH}_{2} \mathrm{Cl}_{2}$ in the back-extraction bottle. MMHg in the $\mathrm{CH}_{2} \mathrm{Cl}_{2}$-phase of the back-extraction bottle was transferred into reagent-grade water by evaporating the $\mathrm{CH}_{2} \mathrm{Cl}_{2}$ in a $70{ }^{\circ} \mathrm{C}$ water bath with continuous $\mathrm{N}_{2}$ purging (Safety note: All manipulations with $\mathrm{CH}_{2} \mathrm{Cl}_{2}$ should be done inside a fume hood). Residual quantities of $\mathrm{CH}_{2} \mathrm{Cl}_{2}$ interfere with MMHg analysis, so all of the $\mathrm{CH}_{2} \mathrm{Cl}_{2}$ must be evaporated. $\mathrm{MMHg}$ in the seawater extracts was determined by gas chromatographic CVAFS with the methods described above for sediments and pore water. The estimated detection limit for a 200-mL seawater sample was about $0.02 \mathrm{pM}$.

\subsection{Estimated sediment-water fluxes of $\mathrm{MMHg}$}

Diffusive fluxes of MMHg from sediments on the continental shelf were estimated similarly to those from LIS (Hammerschmidt et al., 2004) and Lavaca Bay (Gill et al., 1999). 
Sediment-water fluxes of dissolved MMHg $(<0.2 \mu \mathrm{m})$, presumably as $\mathrm{CH}_{3} \mathrm{HgSH}^{0}$ (Dyrssen and Wedborg, 1991), were calculated from the concentration gradient between pore waters of surface sediments and water sampled below the seasonal thermocline (30 m) at each location, which ranged between $0.17 \mathrm{pM}$ and $0.44 \mathrm{pM}$. MMHg was measured in filtered pore water of surface sediment in three cores from each station. The mean concentration of dissolved MMHg between the $0-1 \mathrm{~cm}$ and $1-2 \mathrm{~cm}$ sediment horizons was used for the pore water value, and the mean concentration was applied to $1.0 \mathrm{~cm}$ depth for the flux calculation. Averaging the pore water concentration in this manner minimizes the potential effect of MMHg dilution in the $0-1 \mathrm{~cm}$ section by inclusion of overlying water, though perceived to be minimal during sediment sectioning, and establishes a defined length $(1 \mathrm{~cm})$ for the flux estimate. Diffusional flux estimates derived from interfacial pore-water concentration gradients provide a reasonable estimate for scaling purposes and comparison within and among systems, although they commonly underestimate the actual flux of MMHg (Choe et al., 2004). Factors such as scavenging and demethylation at the sediment-water interface as well as bioirrigation of pore fluids can result in considerable differences between estimated diffusional and actual benthic fluxes.

\subsection{Ancillary geochemistry of sediment}

Several geochemical properties of sediment were measured to assess their relationship to Hg speciation and methylation potential. Standard gravimetric techniques were used to measure the organic content (loss on ignition, LOI) and density of lyophilized sediments (Heiri et al., 2001). The fraction of sediment with a diameter $\leq 63 \mu \mathrm{m}$ (silt + clay) was determined 
gravimetrically after sieving. Dissolved sulfide and oxygen were profiled electrochemically within 1 h of sediment sampling (Visscher et al., 1992). Dissolved sulfide was less than the detection limit (about $10 \mu \mathrm{M}$ ) in the upper $8 \mathrm{~cm}$ of sediment at each site. Dissolved oxygen at the sediment-water interface was comparable to that in overlying water and penetrated no deeper than $0.8 \mathrm{~cm}$ in all sediment cores. AVS was measured with colorimetric techniques (Trüper and Schlegal, 1964).

\subsection{Quality assurance of $\mathrm{Hg}$ dterminations}

Trace-metal clean procedures were employed throughout collection, processing, and analysis of sediment and water samples (Gill and Fitzgerald, 1985). All equipment was cleaned rigorously with acid and rinsed with reagent-grade water. Chemical reagents were suitable for each analysis (Trace Metal or ACS grade). Analyses of total Hg in pore water were calibrated with aliquots of $\mathrm{Hg}^{0}$ taken from the headspace over pure liquid (Gill and Fitzgerald, 1987) and verified by comparison to analyses of aqueous $\mathrm{Hg}^{2+}$ standards traceable to the U.S. National Institute of Standards and Technology (NIST). Recovery of aqueous Hg averaged 103\% (range, 96-108\%) compared to $\mathrm{Hg}^{0}$ standards. Analyses of total $\mathrm{Hg}$ in sediments with the DMA-80 were calibrated with the same aqueous $\mathrm{Hg}^{2+}$ standard. Sample MMHg was measured after calibration with aliquots of a MMHg standard solution, which was calibrated before each use against $\mathrm{Hg}^{0}$ standards and a NIST-traceable aqueous Hg standard.

The precision and bias of our measurements of total Hg and MMHg were estimated by analyses of (1) procedural blanks taken through the digestion or distillation process, (2) certified reference materials for total Hg in marine sediment (MESS-3 and PACS-2; National Research 
Council of Canada), (3) replicate subsamples of sediment and pore water, and (4) spiked subsamples of sediment and pore water (MMHg only). All analyses of total Hg in both reference materials were within their respective certified ranges. The precision of total Hg measurements averaged 6.3\% RSD (range, $0.1-13.3 \%$ ) for sediments and pore waters combined. The precision of MMHg determinations averaged 6.8\% RSD (range, 0.3-20.5\%) for pore water and sediment determinations. The mean recovery of MMHg was 104\% (95\% confidence interval, 100-108\%) from 17 procedurally spiked distillates. Estimated detection limits (pmol g ${ }^{-1}$ dry weight) for a 0.5-g sample were about 1 for total Hg and 0.02 for MMHg. Detection limits for 5-mL aliquots of pore water were about $2 \mathrm{pM}$ for total $\mathrm{Hg}$ and $1 \mathrm{pM}$ for MMHg.

\section{Results and discussion}

\subsection{Hg in surface sediments}

Surface sediments (upper three $\mathrm{cm}$ ) on the continental shelf of southern New England have relatively low concentrations of $\mathrm{Hg}$ (II) and MMHg (Table 1). Hg(II) ranges from 32 to 169 pmol g ${ }^{-1}$ dry weight and MMHg ranges $0.05-1.55 \mathrm{pmol} \mathrm{g}^{-1}$ among our sampling locations. These concentrations are 2-3 fold less than those in sandy, low-organic deposits of central LIS (i.e., ELIS site; Hammerschmidt and Fitzgerald, 2004) and 10-100 times less than those in western LIS (Hammerschmidt et al., 2004) and many other near-shore marine sediments (e.g., Mason and Lawrence, 1999; Bloom et al., 1999; Mikac et al., 1999; Conaway et al., 2003; Choe et al., 2004; Stoichev et al., 2004). Rivers, including Hg that is atmospherically deposited and subsequently leached from the watershed, and industrial/municipal wastewater discharges are major sources of Hg to coastal embayments (Mason et al., 1999; Balcom et al., 2004). The 
relatively low levels of $\mathrm{Hg}(\mathrm{II})$ in the shelf sediments reflect their distance from these sources and the efficient scavenging of $\mathrm{Hg}(\mathrm{II})$ by particles in near-shore waters.

We assessed the spatial heterogeneity of Hg species in the solid and pore water phases of surface sediments at each of the three sampling locations (Table 1). Three sediment cores for Hg analysis were collected at each station; one of the cores was sampled from a separate box core. There is little variation in solid-phase MMHg and $\mathrm{Hg}(\mathrm{II})$ among replicate cores at each station (Table 1); the RSD of Hg concentrations ranges from 10\% to 13\% for MMHg and 4-14\% for Hg(II). Differences in solid-phase Hg concentrations among cores at each station are only slightly greater than the average analytical precision of our measurements (i.e., about 7\% RSD). Moreover, levels of MMHg and Hg(II) in sediment are often closely related to the organic content of coastal marine surface sediments (Varekamp et al., 2000; Hammerschmidt and Fitzgerald, 2004), and some of the variability in the concentration of Hg species among cores at each location may be attributed to differences in organic content (Table 1). MMHg and Hg(II) in pore water are more variable than levels in the solid phase among cores at each station, and range from $6 \%$ to $42 \%$ RSD (Table 1 ), comparable to the variation observed in surface sediments at sites in Lavaca Bay, Texas (Bloom et al., 1999).

The distribution of solid-phase Hg species is correlated strongly with organic matter in surface sediments (upper $3 \mathrm{~cm}$ ) on the continental shelf of southern New England (Fig. 2). The error associated with these measures averages 2\% RSD of the mean for LOI and, as noted, 6-7\% RSD for Hg species. Although the relationships in Figure 2 are limited in spatial coverage (i.e., no samples in 3-5\% LOI range), we have observed comparable correlations between concentrations of Hg species and organic matter in surface sediments of LIS (Hammerschmidt 
and Fitzgerald, 2004). Slopes of the relationships in LIS (175 \pm 10 for $\mathrm{Hg}$ (II) and $1.40 \pm 0.13$ for MMHg), however, are about 10-fold greater than in the shelf sediments (Fig. 2), and differences in slope values between the two study areas likely reflect the proximity of LIS deposits to pollution sources of Hg, rather than differences in the affinity of Hg species for sedimentary organic material (discussed below). The affinity of Hg(II) for organic matter is well known, both in coastal waters (e.g., Coquery et al., 1997; Lamborg et al., 2004) and sediments (e.g., Lindberg and Harriss, 1974; Hammerschmidt et al., 2004), and the relation in Figure 2a results from scavenging of $\mathrm{Hg}(\mathrm{II})$ in the water column by organic particles. Similarly, the relationship in Figure 2b likely results from sedimentary organic matter scavenging MMHg produced within the sediment, although the potential for MMHg accumulation through deposition to the seafloor cannot be discounted. The $y$-intercept values in Figure 2 indicate that nearly all of the Hg(II) and MMHg is associated with organic material.

MMHg is related positively to Hg(II) in sediments on the continental shelf (Fig. 3), as might be expected given the covariation of $\mathrm{Hg}$ species with organic matter (Fig. 2). Although levels of both MMHg and Hg(II) in sediments on the shelf are much less than those in LIS, the average ratio of $\mathrm{MMHg}$ to $\mathrm{Hg}(\mathrm{II})$ is comparable between the two study areas; the slope of the regression for shelf sediments is $0.0076 \pm 0.0006$ (Fig. 3) and the mean MMHg:Hg(II) concentration ratio in LIS sediments is $0.0083 \pm 0.0005$ (Fig. 9 in Hammerschmidt and Fitzgerald, 2004). Moreover, and although levels of MMHg and Hg(II) can vary 10-10² within a particular system, Figure 4 shows that mean MMHg:Hg(II) concentration ratios in surface sediments are constrained to a relatively narrow range among these and other coastal marine systems having considerable differences in climatology, geography, and Hg contamination. The 
slope of Figure 4 indicates an average MMHg:Hg(II) ratio of 0.005 , or about $0.5 \%$ MMHg. This extended perspective of average MMHg:Hg(II) concentration ratios suggests a similar and ubiquitous mechanism may influence the solid-phase concentration of MMHg relative to $\mathrm{Hg}$ (II) in surface sediments of coastal marine systems. We have posited that nearly constant sediment MMHg:Hg(II) concentration ratios within a coastal marine system result from proportional sediment-water partitioning and solid-phase retention of the two Hg species, and that organic matter largely controls the partitioning (Hammerschmidt and Fitzgerald, 2004). The relationship in Figure 4 suggests this hypothesis may have broader applicability, although MMHg: $\mathrm{Hg}(\mathrm{II})$ concentration ratios can be very different in non-marine and highly contaminated systems.

\subsection{Sediment-water partitioning of $\mathrm{Hg}$ species}

We have shown that organic matter exerts a primary control on the sediment-water partitioning of Hg species in LIS sediments, and by extension, other comparable coastal marine deposits (Hammerschmidt and Fitzgerald, 2004; Hammerschmidt et al., 2004). In this study, distribution coefficients $\left(K_{\mathrm{D}}, \mathrm{L} \mathrm{kg}^{-1}\right)$ for both MMHg and $\mathrm{Hg}(\mathrm{II})$ are related positively to the organic content of sediments on the continental shelf (Fig. 5). Data for LIS sediments (Hammerschmidt et al., 2004) also are presented in Figure 5. These relationships are very robust as they include samples from different study areas, sampling locations and periods, sediment depths (up to $15 \mathrm{~cm}$ ), and widely varying $\mathrm{Hg}$ concentrations in solid and pore water phases of sediment. With data from both this study and LIS combined, the relation between the $K_{\mathrm{D}}$ of $\mathrm{Hg}(\mathrm{II})\left(K_{\mathrm{D}(\mathrm{HgII})}\right)$ and organic content of sediments (\% LOI) is described by the regression equation $\left(r^{2}=0.75, n=102\right)$ 


$$
\log K_{\mathrm{D}(\mathrm{HgII})}=(3.13 \pm 0.05)+(0.15 \pm 0.01)[\% \mathrm{LOI}]
$$

Similarly, the relationship between the $K_{\mathrm{D}}$ of $\mathrm{MMHg}\left(K_{\mathrm{D}(\mathrm{MMHg})}\right)$ and organic content of sediment is described by the equation $\left(r^{2}=0.75, n=105\right)$

$$
\log K_{\mathrm{D}(\mathrm{MMHg})}=(1.55 \pm 0.05)+(0.13 \pm 0.01)[\% \mathrm{LOI}]
$$

These strong relationships, across a wide range of physicochemical sedimentary characteristics, show clearly the predominant role of organic matter in influencing the sediment-water partitioning of Hg species in coastal marine sediments. Additionally, and given the similarity of Hg species partitioning with organic matter between these systems, it appears that the Hgcomplexing quality of organic matter in LIS deposits is comparable to that in more distant regions on the continental shelf, where organic material is presumed to be entirely autochthonous. This suggests that much of the sedimentary organic matter in LIS also may be derived from marine plankton.

Sediment-water partitioning of Hg species is controlled largely by the concentration of sedimentary organic matter (Fig. 5), and the slope of the relationship between the $\log K_{\mathrm{D}}$ of MMHg and sedimentary organic content is comparable to that for $\mathrm{Hg}(\mathrm{II})$ (equations 1 and 2). This means that the affinity of MMHg for sedimentary organic matter is proportional to that of $\mathrm{Hg}(\mathrm{II})$, and suggests that the concentration of MMHg in the solid phase of sediment should be proportional to $\mathrm{Hg}(\mathrm{II})$ at steady state. Thus, the relatively constant MMHg:Hg(II) concentration ratios observed in surface sediments within (Fig. 3, this study; Fig. 9 in Hammerschmidt and Fitzgerald, 2004) and among (Fig. 4) coastal marine systems may be related to proportional sediment-water partitioning of the Hg species (Fig. 5). 


\subsection{Hg methylation}

Potential gross rates of ${ }^{200} \mathrm{Hg}$ methylation in shelf sediments are related positively to the concentration of $\mathrm{Hg}(\mathrm{II})$ in $0.2-\mu \mathrm{m}$ filtered pore waters (Fig. 6), which includes both dissolved and colloidal $\mathrm{Hg}(\mathrm{II})$. In contrast, ${ }^{200} \mathrm{Hg}$ methylation potentials are unrelated, if not inversely related, to solid-phase $\mathrm{Hg}(\mathrm{II})(r=-0.56, p=0.002)$. It is presumed that $\mathrm{Hg}(\mathrm{II})$ must be dissolved to enter a bacterial cell and be methylated, and that Hg(II) most likely enters by passive diffusion through the cellular membrane as a dissolved, neutrally charged complex (Benoit et al., 1999a). Sulfide controls the speciation of dissolved Hg-S complexes, and $\mathrm{HgS}^{0}$ is presumed to be the Hg-S complex most available to bacteria in pore water (Benoit et al., 1999a, 1999b, 2001). We infer from the chemical speciation model of Benoit and coworkers (1999b) that $\mathrm{HgS}^{0}$ is a major complex of dissolved $\mathrm{Hg}(\mathrm{II})$ in sediments on the continental shelf, where dissolved sulfide is less than $10 \mu \mathrm{M}$ (detection limit). Accordingly, a positive relationship might be expected between ${ }^{200} \mathrm{Hg}$ methylation and $\mathrm{Hg}(\mathrm{II})$ in pore water if $\mathrm{HgS}^{0}$ were the limiting reactant and a relatively constant or major fraction of dissolved Hg(II). We have found comparable relationships between ${ }^{200} \mathrm{Hg}$ methylation and the concentration of $\mathrm{Hg}(\mathrm{II})$ in $0.2-\mu \mathrm{m}$ filtered pore water of LIS sediments having less than $10 \mu \mathrm{M}$ dissolved sulfide (Hammerschmidt and Fitzgerald, 2004). This suggests there is excess methylating potential in these coastal marine deposits, and MMHg production is limited by the availability of dissolved $\mathrm{Hg}$ (II) (i.e., $\mathrm{HgS}^{0}$ ) to methylating bacteria. This means that environmental factors that affect the level of $\mathrm{HgS}^{0}$ in sediment pore water will influence the gross rate of MMHg production. These factors can include loadings of $\mathrm{Hg}(\mathrm{II})$, the concentration of dissolved sulfide (controlling the speciation of dissolved Hg-S complexes), and sedimentary organic content. Indeed, potential rates of ${ }^{200} \mathrm{Hg}$ 
methylation in shelf sediments are related inversely with the $K_{\mathrm{D}}$ of $\mathrm{Hg}(\mathrm{II})$ (Fig. 7), which is governed largely by the organic content of sediments (Fig. 5). Thus, sediments with less organic matter have proportionately more $\mathrm{Hg}(\mathrm{II})$ in the dissolved phase (i.e., lower $K_{\mathrm{D}}$ ) and the potential for Hg methylation is enhanced (Fig. 7). Comparable relationships between ${ }^{200} \mathrm{Hg}$ methylation potential and the $K_{\mathrm{D}}$ of $\mathrm{Hg}(\mathrm{II})$ were observed in LIS (Hammerschmidt and Fitzgerald, 2004).

\subsubsection{Gross $\mathrm{Hg}$ methylation and sediment $\mathrm{MMHg}$}

Solid-phase concentrations of MMHg in sediments often are correlated with gross $\mathrm{Hg}$ methylation potentials assayed with short-term incubation experiments (e.g., Benoit et al., 2003; Sunderland et al., 2004; Heyes et al., 2004). Hg(II) is the substrate for MMHg production, and because $\mathrm{Hg}(\mathrm{II})$ varies among locations and sediment depths, potential relationships between sediment MMHg and Hg methylation potentials should be evaluated by normalizing either the methylation rate or the ambient MMHg concentration for the level of $\mathrm{Hg}(\mathrm{II})$. Figure 8a shows a modest $(r=0.58)$, but significant $(p<0.001)$, correlation between ambient MMHg concentration and MMHg production potential in sediments on the continental shelf. MMHg production potentials in Figure 8a (pmol MMHg g ${ }^{-1}$ dry sediment $\mathrm{h}^{-1}$ ) are calculated as the product of the potential gross rate of ${ }^{200} \mathrm{Hg}$ methylation $\left(\% \mathrm{~d}^{-1}\right)$ and the ambient concentration of $\mathrm{Hg}(\mathrm{II})$ in the solid phase (pmol g ${ }^{-1}$ dry weight). This normalizes the ${ }^{200} \mathrm{Hg}$ methylation potential for differences in ambient $\mathrm{Hg}$ (II) among samples, and assumes that ambient $\mathrm{Hg}(\mathrm{II})$ has the same availability as added ${ }^{200} \mathrm{Hg}$. Assays of Hg methylation with added isotopes, however, overestimate the production of MMHg from ambient $\mathrm{Hg}(\mathrm{II})$ because added $\mathrm{Hg}$ is more available for methylation (Benoit et al., 2003). This is apparent for surface sediments on the continental 
shelf where estimated hourly MMHg production potentials are a substantial fraction of the ambient MMHg concentration (Fig. 8a).

Sediment MMHg also is not correlated strongly with gross Hg methylation potentials in continental shelf sediments when the concentration of MMHg is normalized for the level of Hg(II) (Fig. 8b). Although the relationship was significant $(p<0.001)$, solid-phase MMHg:Hg(II) concentration ratios are correlated weakly ( $r=0.53$ ) with ${ }^{200} \mathrm{Hg}$ methylation potentials (\% $\mathrm{d}^{-1}$; Fig. 8b) in the same sediment samples shown in Figure 8a. The relatively low correlation coefficients for the relationships in Figures 8a and 8b suggest that the gross rate of Hg methylation is not a major factor influencing solid-phase MMHg concentrations in sediments on the continental shelf. The absence of a strong relationship between these two variables might be expected given that ${ }^{200} \mathrm{Hg}$ methylation potentials can vary widely (e.g., Fig. 6) and that MMHg:Hg(II) concentration ratios in the solid phase are relatively constant (Fig. 3). We have observed previously that potential rates of $\mathrm{Hg}$ methylation are unrelated to MMHg:Hg(II) concentration ratios in the upper four cm of LIS deposits (Hammerschmidt and Fitzgerald, 2004). As hypothesized, this was attributed to proportional sediment-water partitioning of Hg species (e.g., Fig. 5), and to particle sorption being a minor sink for MMHg relative to its diffusional efflux to overlying water.

\subsubsection{Gross Hg methylation and sediment-water $M M H g$ flux}

If mobilization to overlying water were a major sink for MMHg produced in sediments, then a positive relationship might be expected between the gross potential rate of MMHg production in surface sediment and its efflux to overlying water. Mean diffusive sediment-water 
fluxes of MMHg from deposits on the continental shelf $\left(\mathrm{pmol} \mathrm{m} \mathrm{m}^{-2} \mathrm{~d}^{-1} \pm 1 \mathrm{SE}\right)$ are $6.6 \pm 0.6$ at 71north, $12 \pm 1.0$ at 71central, and $8.2 \pm 1.7$ at 71south, based on three replicate cores at each location. Figure 9 shows that sediment-water fluxes of MMHg are related positively to average gross MMHg production potentials in the upper two cm of sediment among the three sampling locations on the continental shelf and three stations in LIS in August 2001 and March 2002. Previously published fluxes (Hammerschmidt et al., 2004) and methylation rates (Hammerschmidt and Fitzgerald, 2004) are combined for the LIS dataset in Figure 9. Potential rates of MMHg production in Figure 9 are estimated as the product of the potential rate of ${ }^{200} \mathrm{Hg}$ methylation $\left(\% \mathrm{~d}^{-1}\right)$ and the ambient concentration of $\mathrm{Hg}(\mathrm{II})$ in the solid phase (pmol g ${ }^{-1}$ dry weight). The upper two cm of sediment were used to calculate the average MMHg production potential in surface sediment because this is the same depth interval used for the flux estimate (Section 2.4).

The relationship in Figure 9 suggests a direct connection between gross rates of MMHg production in coastal marine sediments and its efflux to overlying water, although estimates of gross MMHg production overestimate the methylation of ambient $\mathrm{Hg}$ (II). The flux of MMHg increases with its estimated production potential in surface sediments on the continental shelf and in LIS, and seasonal variations in MMHg flux correspond to differences in MMHg production among the three locations in LIS (Fig. 9). Moreover, the $y$-intercept of this relationship indicates little or no MMHg efflux without active production (Fig. 9). This relationship is striking because the flux of MMHg from sediments may be interpreted as a proxy of net MMHg production at steady state (i.e., gross Hg methylation after losses to abiotic/biological demethylation, bioaccumulation, and particle adsorption). However, and 
given the uncertainty associated with the fraction of ambient $\mathrm{Hg}(\mathrm{II})$ that is available for methylation, the difference between MMHg production potential (i.e., gross production) and its flux from sediment (net production) does not allow quantitative evaluation of the rate of loss to these sinks. Nevertheless, environmental factors that affect the sedimentary accumulation of $\mathrm{Hg}(\mathrm{II})$ and/or its gross rate of methylation may influence the net production and mobilization of MMHg from coastal marine deposits. We hypothesize that there is excess methylating potential

in coastal marine sediments based on observed relationships between ${ }^{200} \mathrm{Hg}$ methylation potential and the level of $\mathrm{Hg}(\mathrm{II})$ in pore water on the continental shelf (Fig. 6) and in LIS (Fig. 8 in Hammerschmidt and Fitzgerald, 2004). Accordingly, loadings of Hg(II) may be an important control on net MMHg production, and this should be assessed by quantification of sediment-water fluxes in addition to solid-phase accumulation of MMHg, which as noted, may be influenced strongly by geochemical properties of sediment particles, namely the concentration of organic matter.

\subsection{Stratigraphy of $\mathrm{Hg}$ species}

The vertical stratigraphy of Hg species and associated sedimentary geochemical parameters at the three stations are presented in Figure 10. Although solid-phase Hg(II) varies considerably among sampling locations (e.g., Table 1), it is homogeneous throughout the upper $10 \mathrm{~cm}$ of sediment at each site and decreases at depths greater than $10 \mathrm{~cm}$ at stations $71 \mathrm{central}$ and 71south (Fig. 10b,c). Similar uniformity of $\mathrm{Hg}(\mathrm{II})$ or total $\mathrm{Hg}$ in the upper $10 \mathrm{~cm}$ of sediment has been observed in other coastal systems (Varekamp et al., 2000; Hammerschmidt et al., 2004; Sunderland et al., 2004; Choe et al., 2004), and, in many cases, it can be attributed to 
the mixing and homogenization of sediment particles by the within-sediment migration of benthic infauna (Benninger et al., 1979). Profiles of $\mathrm{Hg}(\mathrm{II})$ in filtered pore water were less homogeneous, but measured concentrations and the $K_{\mathrm{D}}$ of $\mathrm{Hg}(\mathrm{II})$ varied by only 2-fold or less with depth at each station (Fig. 10). Vertical uniformity in the $K_{\mathrm{D}}$ of $\mathrm{Hg}(\mathrm{II})$ also has been observed in sediments of LIS (Hammerschmidt et al., 2004) and other coastal marine embayments (Bloom et al., 1999; Choe et al., 2004). This may be attributed to organic matter, a major control on sediment-water partitioning of Hg species (Fig. 5), having a relatively constant concentration in the upper $10 \mathrm{~cm}$ of coastal marine sediments (Hammerschmidt et al., 2004). A marked peak in the profile of dissolved Hg(II) at station 71south corresponded with depth horizons of maximum MMHg concentrations in the solid and pore water phases (Fig. 10c).

MMHg varies with sediment depth at each location (Fig. 10). Solid-phase concentrations of MMHg are maximum 3-6 cm below the sediment-water interface, and decrease gradually with increasing depth. Profiles of MMHg in filtered pore water are comparable to those in the solid phase at stations 71central and 71south, but not at 71north. MMHg averages 27\% of total Hg (range, 7-62\%) in pore water among all stations and sediment depths, a fraction much greater than that in the solid phase of sediment (mean, $0.66 \%$ ).

Hg is actively methylated throughout the upper $10 \mathrm{~cm}$ of sediment on the continental shelf (Fig. 10). Profiles of ${ }^{200} \mathrm{Hg}$ methylation potential exhibit four characteristics that are common among all or most of the locations: (1) profiles of ${ }^{200} \mathrm{Hg}$ methylation potentials show a broad subsurface maximum, generally between 3 and $6 \mathrm{~cm}$ depth, and a gradual decline with increasing depth; (2) the depths of ${ }^{200} \mathrm{Hg}$ methylation maxima coincide generally with those of peak MMHg concentrations in the solid phase; (3) potential rates of ${ }^{200} \mathrm{Hg}$ methylation are 
reduced at sediment depths where AVS was relatively enhanced (stations 71north and 71central only); and (4) peaks in ${ }^{200} \mathrm{Hg}$ methylation potentials correspond with maximal values in the bioturbation index (station 71north and 71south only). The bioturbation index (Hammerschmidt et al., 2004) is a geochemical measure of non-local physical disturbance of the sedimentary column, presumably by benthic infauna, that indicates the relative degree of change in organic content between vertically adjacent sections of sediment. Accordingly, relatively large changes in the organic content of adjacent sedimentary horizons are indicated by greater bioturbation index values.

Bioturbation may enhance MMHg production in sediments on the continental shelf. Bioturbation index values $>0.1$ generally are indicative of non-local sediment disturbance (Hammerschmidt et al., 2004). The greatest potential rates of ${ }^{200} \mathrm{Hg}$ methylation at 71 north are in the upper $6 \mathrm{~cm}$ of sediment, a zone that also had bioturbation index values greater than 0.1 (Fig. 10a). Moreover, the profile of ${ }^{200} \mathrm{Hg}$ methylation at 71 south is irregular in shape; it has a subsurface maximum in the 10-12 cm depth horizon that was observed in both of the cores assayed for Hg methylation potentials (Fig. 10c). This peak in ${ }^{200} \mathrm{Hg}$ methylation, as well as the broad one at 4-6 cm depth, coincides with maxima in the bioturbation index at 71south (Fig. 10c). The zoobenthic community at 71north is dominated by polychaete worms and amphipod crustaceans, whereas brittle stars, Axiognathus squamatus and Amphioplus abdius, are the most abundant macrofauna at 71south. The potential effect of non-local sediment disturbance on Hg methylation is supported by profiles at 71central where bioturbation index values are low $(<0.1)$ and ${ }^{200} \mathrm{Hg}$ methylation potentials are relatively low with no anomalous subsurface peaks (Fig. 10b), as well deeper sediments at 71north, where bioturbation index values and potential rates of 
Hg methylation are less than those nearer the surface (Fig. 10a). Hence, physically disturbed sediments, as indicated by the bioturbation index, may be more conducive for active $\mathrm{Hg}$ methylation, although the reason for this is unknown (Hammerschmidt et al., 2004). We have previously observed relationships between maxima in the bioturbation index and enhanced $\mathrm{Hg}$ methylation potentials in sediments of LIS (Hammerschmidt et al., 2004), and Sunderland and coworkers (2004) noted enhanced MMHg production in deposits disturbed by tidal currents in the Bay of Fundy.

\subsection{Sediment-water flux of $\mathrm{MMHg}$}

Estimated diffusive fluxes of MMHg from sediments on the continental shelf are relatively low compared to those from sediments nearer to shore and fluvial sources of anthropogenic Hg. As noted, the mean sediment-water fluxes of MMHg $\left(\mathrm{pmol} \mathrm{m}^{-2} \mathrm{~d}^{-1}, \pm 1 \mathrm{SE}\right.$; $n=3$ ) are $6.6 \pm 0.6$ at 71 north, $12 \pm 1.0$ at 71 central, and $8.2 \pm 1.7$ at 71 south. These fluxes are $10-10^{2}$ less than those estimated or measured for sediments in near-shore embayments, including LIS (basin-wide mean, $47 \mathrm{pmol} \mathrm{m}^{-2} \mathrm{~d}^{-1}$; Hammerschmidt et al., 2004), Lavaca Bay (mean, 210 pmol m $\mathrm{m}^{-2} \mathrm{~d}^{-1}$; Gill et al., 1999), and a site in the Gulf of Trieste, northern Adriatic Sea (2300 pmol m${ }^{-2} \mathrm{~d}^{-1}$; Covelli et al., 1999). Direct atmospheric deposition is the presumed primary source of $\mathrm{Hg}(\mathrm{II})$ to sediments at our sampling locations on the continental shelf, whereas sediment Hg loadings in LIS, Lavaca Bay, and the Gulf of Trieste are enhanced by fluvial sources of $\mathrm{Hg}$, both from atmospheric deposition and anthropogenic activities in the watershed (Covelli et al., 1999; Gill et al., 1999; Hammerschmidt et al., 2004). 
Given the substantial sedimentary efflux of MMHg in LIS, we hypothesized previously that diffusion from sediments in the coastal zone may be a significant source of MMHg to biota in the ocean (Hammerschmidt et al., 2004). This is in contrast to the hypothesis that most of the MMHg in marine fish results from potential methylation sources in the deep ocean such as hydrothermal systems and sediments (Kraepiel et al., 2003). Although the source of MMHg in marine fish is largely unknown, Rolfhus and Fitzgerald (1995) estimated that an annual flux of about $0.2 \mathrm{Mmol} \mathrm{MMHg}$ to the ocean is required to sustain the average concentration in marine fish ( $\sim 0.2 \mu \mathrm{g} \mathrm{g}^{-1}$ wet weight). If sediments of the coastal zone, which is about $10 \%$ of the area of the global ocean, were the primary source of MMHg, then we estimate that a flux of about 15 pmol $\mathrm{m}^{-2} \mathrm{~d}^{-1}$ is required to sustain this bioaccumulative uptake. The average diffusional flux of MMHg from sediments at our sampling locations on the continental shelf averages $9 \mathrm{pmol} \mathrm{m}^{-2}$ $\mathrm{d}^{-1}$ at a mean sediment temperature of $15{ }^{\circ} \mathrm{C}$. This flux, estimated from just three stations on the shelf of the northwestern Atlantic, is within a factor of two of that needed to sustain that annual bioaccumulative uptake of MMHg by marine fish (i.e., $15 \mathrm{pmol} \mathrm{m}^{-2} \mathrm{~d}^{-1}$ ). Moreover, the benthic flux of MMHg from the coastal zone may be enhanced considerably by mobilization from sediments that are impacted more severely by anthropogenic Hg. For example, and as noted, fluxes of MMHg from deposits in LIS, Lavaca Bay, and the Gulf of Trieste are considerably greater than those estimated for the shelf sediments sampled in this study.

\section{6. $M M H g$ in continental shelf water}

The geographical and vertical distribution of MMHg in water on the continental shelf of southern New England also suggests that in situ sedimentary production may be an important 
source of MMHg to the shelf and possibly the open ocean. Levels of dissolved $(<0.2-\mu \mathrm{m}$ filtered) and particle-associated MMHg in surface water (1 m), and water sampled below the seasonal thermocline (30 m), increase with distance from shore and total water column depth among stations (Fig. 11). That is, MMHg in surface and sub-thermocline water is considerably greater at 71south (131 m water depth) than at 71north (59 m). MMHg in the dissolved phase is a consistent fraction of total MMHg among the six samples (mean, 85\%; range 80-89\%). The trends in Figure 11 are inconsistent with rivers or estuaries being a major source of MMHg to these waters on the shelf and indicate that there is a significant in situ source of MMHg. Moreover, levels of dissolved and particulate MMHg are enhanced in water below the seasonal thermocline compared to surface water at each station (Fig. 11), suggesting that mobilization from sediments may be the major source of MMHg. Finally, concentrations of dissolved MMHg in shelf waters are much greater than those in the mixed layer of the open ocean $(\leq 0.05 \mathrm{pM}$; Mason and Fitzgerald, 1993; Mason et al., 1995), and are thereby a source of MMHg. This is consistent with our hypothesis that sediments in the coastal zone, including those on the continental shelf, may be a potentially significant source of MMHg to the ocean and its biota.

\section{Summary}

The biogeochemical cycling of MMHg in sediments on the continental shelf is similar to that in near-shore systems such as LIS, although levels of $\mathrm{Hg}$ species in shelf deposits are considerably less. The concentration of $\mathrm{Hg}(\mathrm{II})$ in pore water, presumably as $\mathrm{HgS}^{0}$ in low-sulfide sediments on the continental shelf and LIS, is a major factor influencing gross potential rates of Hg methylation, suggesting that MMHg production is limited by the availability of $\mathrm{Hg}$ (II) in 
coastal marine deposits. Moreover, the diffusional benthic efflux of MMHg (i.e., net production) is related positively to its gross potential rate of production. This suggests that loadings of Hg(II), most of which are presumably from atmospheric deposition on the continental shelf and in near-shore environs like LIS (Balcom et al., 2004), may be an important factor influencing the gross and net production of MMHg and its flux to overlying water. Although anthropogenic sources have increased loadings of $\mathrm{Hg}(\mathrm{II})$ to near-shore deposits (Balcom et al., 2004), it is unclear if shelf sediments more distant from human and fluvial sources have been impacted similarly. Atmospheric deposition is the principal source of Hg in remote locations (Fitzgerald et al., 1998), and atmospheric Hg loadings have increased 2-4 fold globally since the Industrial Revolution (Lamborg et al., 2002). If atmospheric deposition were the primary source of Hg to continental shelf sediments, then it is likely that the production, sedimentary mobilization, and accumulation of MMHg in marine biota have increased proportionately. This is of particular human toxicological significance, given that most of the fish consumed by humans is of marine origin and that about $75 \%$ of marine fish productivity is supported by the coastal zone.

\section{Acknowledgments}

We thank Prentiss Balcom, Laura Baumgartner, Max Chen, Eileen Ekstrom, Jeff Godfrey, Larissa Graham, Elizabeth Malcolm, François Morel, Heather Pugh, Degui Tang, George Waldbusser, and the captain and crew of the R/V Connecticut for help with either sample collection or analysis. We are grateful to Jani Benoit, Robert Byrne, and two anonymous reviewers for helpful comments on an earlier draft of this manuscript. This research was supported by a STAR student fellowship (U91591801) and grant (R827635) from the U.S. 
Environmental Protection Agency, a graduate student fellowship and grant from the Hudson River Foundation for Environmental Research, and the Postdoctoral Scholar Program at the Woods Hole Oceanographic Institution, with funding provided by the Doherty Foundation. The research described in this article does not necessarily reflect the views of the U.S. EPA, and no official endorsement should be inferred.

\section{References}

Balcom P. H., Fitzgerald W. F., Vandal G. M., Lamborg C. H., Rolfhus K. R., Langer C. S., and Hammerschmidt C. R. (2004) Mercury sources and cycling in the Connecticut River and Long Island Sound. Mar Chem. 90, 53-74.

Benninger L. K., Aller R. C., Cochran J. K., and Turekian K. K. (1979) Effects of biological sediment mixing on the ${ }^{210} \mathrm{~Pb}$ chronology and trace metal distribution in a Long Island Sound sediment core. Earth Planet. Sci. Lett. 43, 241-259.

Benoit J. M., Gilmour C. C., Mason R. P., Riedel G. S., and Riedel G. F. (1998) Behavior of mercury in the Patuxent River estuary. Biogeochemistry 40, 249-265.

Benoit J. M., Mason R. P., and Gilmour C. C. (1999a) Estimation of mercury-sulfide speciation in sediment pore waters using octanol-water partitioning and implications for availability to methylating bacteria. Environ. Toxicol. Chem. 18, 2138-2141.

Benoit J. M., Gilmour C. C., and Mason R. P. (1999b) Sulfide controls on mercury speciation and bioavailability to methylating bacteria in sediment pore waters. Environ. Sci. Technol. 33, 951-957. 
Benoit J. M., Gilmour C. C., and Mason R. P. (2001) The influence of sulfide on solid-phase mercury bioavailability for methylation by pure cultures of Desulfobulbus propionicus (1pr3). Environ. Sci. Technol. 35, 127-132.

Benoit J. M., Gilmour C. C., Heyes A., Mason R. P., and Miller C. L. (2003) Geochemical and biological controls over methylmercury production and degradation in aquatic ecosystems. In Biogeochemisty of Environmentally Important Trace Elements (eds. Y. Cai, O. C. Braids), pp. 262-297. American Chemical Society, Washington, DC, pp. $262-297$.

Bloom N. S. (1989) Determination of picogram levels of methylmercury by aqueous phase ethylation, followed by cryogenic gas chromatography, with cold vapour atomic fluorescence detection. Can. J. Fish. Aquat. Sci. 46, 1131 !1140.

Bloom N. S., Colman J. A., and Barber L. (1997) Artifact formation of methyl mercury during aqueous distillation and alternative techniques for the extraction of methyl mercury from environmental samples. Fresenius' J. Anal. Chem. 358, 371-377.

Bloom N. S., and Fitzgerald W. F. (1988) Determination of volatile mercury species at the picogram level by low-temperature gas chromatography with cold-vapor atomic fluorescence detection. Anal. Chim. Acta 208, 151-161.

Bloom N. S., Gill G. A., Cappellino S., Dobbs C., McShea L., Driscoll C., Mason R., and Rudd J. (1999) Speciation and cycling of mercury in Lavaca Bay, Texas, sediments. Environ. Sci. Technol. 33, 7-13. 
Choe K.-Y., Gill G. A., Lehman R. D., Han S., Heim W. A., and Coale K. H. (2004)

Sediment-water exchange of total mercury and monomethyl mercury in the San Francisco Bay-Delta. Limnol. Oceanogr. 49, 1512-1527.

Conaway C. H., Squire S., Mason R. P., and Flegal A. R. (2003) Mercury speciation in the San Francisco Bay estuary. Mar. Chem. 80, 199-225.

Coquery M., Cossa D., and Sanjuan J. (1997) Speciation and sorption of mercury in to macrotidal estuaries. Mar. Chem. 58, 213-227.

Covelli S., Faganeli J., Horvat M., and Brambati A. (1999) Porewater distribution and benthic flux measurements of mercury and methylmercury in the Gulf of Trieste (Northern Adriatic Sea). Estuar. Coast. Shelf Sci. 48, 415-428.

Dyrssen D., and Wedborg M. (1991) The sulfur-mercury(II) system in natural waters. Water Air Soil Pollut. 56, 507-519.

Fitzgerald W. F., and Clarkson T. W. (1991) Mercury and monomethylmercury: Present and future concerns. Environ. Health Pers. 96, 159!166.

Fitzgerald W. F., Engstrom D. R., Mason R. P., and Nater E. A. (1998) The case for atmospheric mercury deposition in remote areas. Environ. Sci. Technol. 32, 1-7.

Fitzgerald W. F., and Gill G. A. (1979) Subnanogram determination of mercury by two-stage gold amalgamation applied to atmospheric analysis. Anal. Chem. 51, 1714!1720.

Gagnon C., Pelletier E., and Mucci A. (1997) Behaviour of anthropogenic mercury in coastal marine sediments. Mar. Chem. 59, 159-176. 
Gill G. A., Bloom N. S., Cappellino S., Driscoll C. T., Mason R., and Rudd J. W. M. (1999) Sediment-water fluxes of mercury in Lavaca Bay, Texas. Environ. Sci. Technol. 33, 663-669.

Gill G. A., and Fitzgerald W. F. (1985) Mercury sampling of open ocean waters at the picomolar level. Deep Sea Res. 32, 287-297.

Gill G. A., and Fitzgerald W. F. (1987) Picomolar mercury measurements in seawater and other materials using stannous chloride and two-stage amalgamation with gas phase detection. Mar. Chem. 20, 227!243.

Hammerschmidt C. R. (2005) The biogeochemical cycling of methylmercury in coastal marine sediments. Ph.D. thesis, Univ. of Connecticut.

Hammerschmidt C. R., and Fitzgerald W. F. (2001) Formation of artifact methylmercury during extraction from a sediment reference material. Anal. Chem. 73, 5930-5936.

Hammerschmidt C. R., and Fitzgerald W. F. (2004) Geochemical controls on the production and distribution of methylmercury in near-shore marine sediments. Environ. Sci. Technol. 38, 1487-1495.

Hammerschmidt C. R., and Fitzgerald W. F. (2005) Methylmercury in mosquitoes related to atmospheric mercury deposition and contamination. Environ. Sci. Technol. 39, 3034-3039.

Hammerschmidt C. R., Fitzgerald W. F., Lamborg C. H., Balcom P. H., and Visscher P. T. (2004) Biogeochemistry of methylmercury in sediments of Long Island Sound. Mar. Chem. 90, 31-52. 
Heiri O., Lotter A. F., and Lemcke G. (2001) Loss on ignition as a method for estimating organic and carbonate content is sediments: Reproducibility and comparability of results. J. Paleolimnol. 25, 101-110.

Heyes A., Miller C., and Mason R. P. (2004) Mercury and methylmercury in Hudson River sediment: Impact of tidal resuspension on partitioning and methylation. Mar. Chem. 90, 75-89.

Hintelmann H., and Evans R. D. (1997) Application of stable isotopes in environmental tracer studies-Measurement of monomethylmercury $\left(\mathrm{CH}_{3} \mathrm{Hg}^{+}\right)$by isotope dilution ICP-MS and detection of species transformation. Fresenius' J. Anal. Chem. 358, 378-385.

Kannan K., and Falandysz J. (1998) Speciation and concentrations of mercury in certain coastal marine sediments. Water Air Soil Pollut. 103, 129-136.

Kehrig H. A., Pinto F. N., Moreira I., and Malm O. (2003) Heavy metals and methylmercury in a tropical coastal estuary and a mangrove in Brazil. Org. Geochem. 34, 661-669.

Klaue B., and Blum J. D. (1999) Trace analyses of arsenic in drinking water by inductively coupled plasma mass spectrometry: High resolution versus hydride generation. Anal. Chem. 71, 1408-1414.

Kraepiel A. M. L., Keller K., Chin H. B., Malcolm E. G., and Morel F. M. M. (2003) Sources and variation of mercury in tuna. Environ. Sci. Technol. 37, 5551-5558.

Lamborg C. H., Fitzgerald W. F., Damman A. W. H., Benoit J. M., Balcom P. H., and Engstrom D. R. (2002) Modern and historic atmospheric mercury fluxes in both hemispheres: Global and regional mercury cycling implications. Global Biogeochem. Cycles 16, 1104. 
Lamborg C. H., Fitzgerald W. F., Skoog A., and Visscher P. T. (2004) The abundance and source of mercury-binding organic ligands in Long Island Sound. Mar. Chem. 90, $151-163$.

Lindberg S. E., and Harriss R. C. (1974) Mercury-organic matter associations in estuarine sediments and interstitial water. Environ. Sci. Technol. 8, 459-462.

Mason R. P., and Fitzgerald W. F. (1993) The distribution and biogeochemical cycling of mercury in the equatorial Pacific Ocean. Deep-Sea Res. 40, 1897-1924.

Mason R. P., and Lawrence A. L. (1999) Concentration, distribution, and bioavailability of mercury and methylmercury in sediments of Baltimore Harbor and Chesapeake Bay, Maryland, USA. Environ. Toxicol. Chem. 18, 2438-2447.

Mason R. P., Rolfhus K. R., and Fitzgerald W. F. (1995) Methylated and elemental mercury cycling in surface and deep ocean waters of the North Atlantic. Water Air Soil Pollut. 80, 665-677.

Mason R. P., Bloom N., Cappellino S., Gill G., Benoit J., and Dobbs C. (1998) Investigation of porewater sampling methods for mercury and methylmercury. Environ. Sci. Technol. 32, 4031-4040.

Mason R. P., Lawson N. M., Lawrence A. L., Leaner J. J., Lee J. G., and Shue G.-R. (1999) Mercury in the Chesapeake Bay. Mar. Chem. 65, 77-96.

Mikac N., Niessen S., Ouddane B., and Wartel M. (1999) Speciation of mercury in sediments of the Seine Estuary (France). Appl. Organomet. Chem. 13, 715-725. 
Mzoughi N., Stoichev T., Dachraoui M., El Abed A., Amouroux D., and Donard O. F. X. (2002) Inorganic mercury and methylmercury in surface sediments and mussel tissues from a macrotidal lagoon (Bizerte, Tunisia). J. Coast. Conserv. 8, 141-145.

Rolfhus K. R., and Fitzgerald W. F. (1995) Linkages between atmospheric mercury deposition and the methylmercury content of marine fish. Water Air Soil Pollut. 80, 291-297.

Ryther J. H. (1969) Photosynthesis and fish production in the sea. Science 166, 72-76.

Stoichev T., Amouroux D., Wasserman J. C., Point D., De Diego A., Bareille G., and Donard O. F. X. (2004) Dynamics of mercury species in surface sediments of a macrotidal estuarine-coastal system (Adour River, Bay of Biscay). Estuar. Coast. Shelf Sci. 59, $511-521$.

Sunderland E. M., Gobas F. A. P. C., Heyes A., Branfireun B. A., Bayer A. K., Cranston R. E., and Parsons M. B. (2004) Speciation and bioavailability of mercury in well-mixed estuarine sediments. Mar. Chem. 90, 91-105.

Trüper H. G., and Schlegel H. G. (1964) Sulfur metabolism in Thiorhodaceae: I. Quantitative measurements on growing cells of Chromatium okenii Ant. Leeuwenhoek. J. Microb. Serol. 30, 225-238.

Tseng C.-M., Amouroux D., Abril G., Tessier E., Etcheber H., and Donard O. F. X. (2001) Speciation of mercury in a fluid mud profile of a highly turbid macrotidal estuary (Gironde, France). Environ. Sci. Technol. 35, 2627-2633.

Tseng C.-M., Hammerschmidt C. R., and Fitzgerald W. F. (2004) Determination of methylmercury in environmental matrixes by on-line flow injection and atomic fluorescence spectrometry. Anal. Chem. 76, 7131-7136. 
Twitchell D. C., McClennen C. E., and Butman B. (1981) Morphology and processes associated with the accumulation of the fine-grained sediment deposit of the southern New England shelf. J. Sed. Petrol. 51, 269-280.

U.S. Environmental Protection Agency. (2002) Estimated per capita fish consumption in the United States, August 2002. EPA-821-C-02-003. U.S. Environmental Protection Agency, Washington, DC.

Varekamp J. C., Buchholtz ten Brink M. R., Mecray E. L., and Kreulen B. (2000) Mercury in Long Island Sound sediments. J. Coast. Res. 16, 613-626.

Visscher P. T., Beukema J., and Van Gemerden H. (1992) In situ characterization of sediments: Measurements of oxygen and sulfide profiles with a novel combined needle electrode. Limnol. Oceanogr. 36, 1476-1480.

Winfrey M. R., and Rudd. J. W. M. (1990) Environmental factors affecting the formation of methylmercury in low pH lakes. Environ. Toxicol. Chem. 9, 853-869. 
Table 1. Mean characteristics of surface sediments (upper three $\mathrm{cm}$ ) at the three sampling stations on the continental shelf of southern New England. The relative standard deviation (\%) among cores at each station $(n=3)$ is given in parentheses.

\begin{tabular}{lcccccc}
\hline & & \multicolumn{2}{c}{$\begin{array}{c}\text { Sediment } \\
\text { (pmol g-1 dry weight })\end{array}$} & & \multicolumn{2}{c}{$\begin{array}{c}\text { Pore water } \\
\text { (pM) }\end{array}$} \\
\cline { 3 - 4 } \cline { 6 - 7 } Station & $\begin{array}{c}\text { Organic content } \\
\text { (\%LOI) }\end{array}$ & MMHg & Hg(II) & & MMHg & $\mathrm{Hg}(\mathrm{II})$ \\
\hline 71 north & 1.9 & 0.36 & 43.0 & & 3.62 & 17.2 \\
& $(11.3)$ & $(10.3)$ & $(14.2)$ & & $(5.6)$ & $(41.7)$ \\
71 central & 6.8 & 1.13 & 158 & & 3.49 & 8.6 \\
& $(4.8)$ & $(10.3)$ & $(4.0)$ & & $(21.8)$ & $(22.9)$ \\
71 south & 5.8 & 0.74 & 96.6 & & 4.41 & 15.5 \\
& $(8.3)$ & $(12.5)$ & $(5.2)$ & & $(16.0)$ & $(18.6)$ \\
\hline
\end{tabular}




\section{Figure captions}

Figure 1. Location of sediment sampling sites on the continental shelf of southern New

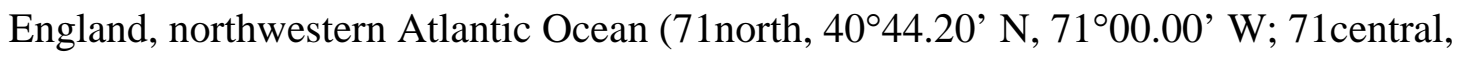
$40^{\circ} 28.00^{\prime} \mathrm{N}, 71^{\circ} 00.00^{\prime} \mathrm{W}$; 71south, $\left.40^{\circ} 12.00^{\prime} \mathrm{N}, 71^{\circ} 00.00^{\prime} \mathrm{W}\right)$.

Figure 2. Relation between the concentration of Hg species and organic content of surface sediments (upper three $\mathrm{cm}$ ) on the continental shelf of southern New England.

Figure 3. MMHg versus $\mathrm{Hg}(\mathrm{II})$ in the upper ten $\mathrm{cm}$ of sediment at three locations on the continental shelf of southern New England.

Figure 4. Relation between reported average concentrations of MMHg and $\mathrm{Hg}(\mathrm{II})$ in surface sediments of different coastal marine systems. $\mathrm{Hg}(\mathrm{II})$ was presumed equal to total $\mathrm{Hg}$ for locations where Hg(II) was not reported; open circle (continental shelf of southern New England; this study); closed circles (South China, Bering, and Baltic Seas; Kannan and Falandysz, 1998); open square (Lagoon of Bizerte, Tunisia; Mzoughi et al., 2002); closed square (Patuxent River estuary, Maryland; Benoit et al., 1998); open triangle up (Bay of Biscay, France; Stoichev et al., 2004); closed triangle up (Long Island Sound, Connecticut/New York; Varekamp et al., 2000; Hammerschmidt and Fitzgerald, 2004); open dotted square (Gironde River estuary, France; Tseng et al., 2001); open triangle down (San Francisco Bay, California; Conaway et al., 2003); closed triangle down (Lavaca Bay, Texas; Bloom et al., 1999); open diamond (Chesapeake Bay, Maryland; Mason and Lawrence, 1999); closed diamond (Seine River estuary, France; Mikac et al., 1999); open hexagon (Saguenay Fjord, Quebec; Gagnon et al., 1997); closed hexagon 
(New York/New Jersey Harbor; Hammerschmidt, 2005); dotted open circle (estuarine section of Guanabara Bay, Brazil; Kehrig et al., 2003).

Figure 5. Variation of the distribution coefficients $\left(K_{\mathrm{D}}\right)$ of $\mathrm{MMHg}$ and $\mathrm{Hg}(\mathrm{II})$ with organic content of sediments, measured as percent loss-on-ignition (\%LOI), on the continental shelf of southern New England and Long Island Sound (LIS). LIS data are from Hammerschmidt et al. (2004).

Figure 6. Correlation between ${ }^{200} \mathrm{Hg}$ methylation potentials and levels of $\mathrm{Hg}$ (II) in pore water of sediments on the continental shelf of southern New England.

Figure 7. ${ }^{200} \mathrm{Hg}$ methylation potential versus the distribution coefficient $\left(K_{\mathrm{D}}\right)$ of $\mathrm{Hg}(\mathrm{II})$ in sediments on the continental shelf of southern New England.

Figure 8. Correlations between solid-phase MMHg and its potential gross rate of production in the upper $12 \mathrm{~cm}$ of sediment on the continental shelf of southern New England: a) ambient MMHg concentration versus potential MMHg production estimated from ambient $\mathrm{Hg}(\mathrm{II})$ and incubations of added ${ }^{200} \mathrm{Hg}$, and b) solid-phase concentration ratio of ambient MMHg:Hg(II) versus ${ }^{200} \mathrm{Hg}$ methylation potential.

Figure 9. Relation between estimated diffusive fluxes of dissolved $\mathrm{MMHg}(<0.2-\mu \mathrm{m}$ filtered) and gross potential rates of MMHg production in the upper two cm of sediment among sampling locations on the continental shelf and in Long Island Sound (LIS) in August 2001 and March 2002 (Hammerschmidt and Fitzgerald, 2004; Hammerschmidt et al., 2004). Error bars are \pm 1 SE of the mean. The uncertainty of LIS flux estimates was not determined. Data for LIS in June 2002 were not included because Hg methylation 
potentials were inhibited and MMHg fluxes enhanced by a seasonal change in sediment biogeochemistry following a spring plankton bloom.

Figure 10. Profiles of solid-phase and pore water $\mathrm{Hg}$ species, ${ }^{200} \mathrm{Hg}$ methylation potentials, and ancillary sediment biogeochemistry at three stations on the continental shelf of southern New England. Hg speciation profiles do not include results from the two surface sediment cores (upper $3 \mathrm{~cm}$ only) at each station. Error bars represent $\pm 1 \mathrm{SE}$ of the mean.

Figure 11. Trends of increasing dissolved (diss; < $0.2-\mu \mathrm{m}$ filtered) and particle-associated (part; $>0.2 \mu \mathrm{m}) \mathrm{MMHg}$ with increasing water column depth in surface (1 m depth) and subthermocline (30m) water on the continental shelf of southern New England. 
Figure 1. Hammerschmidt \& Fitzgerald

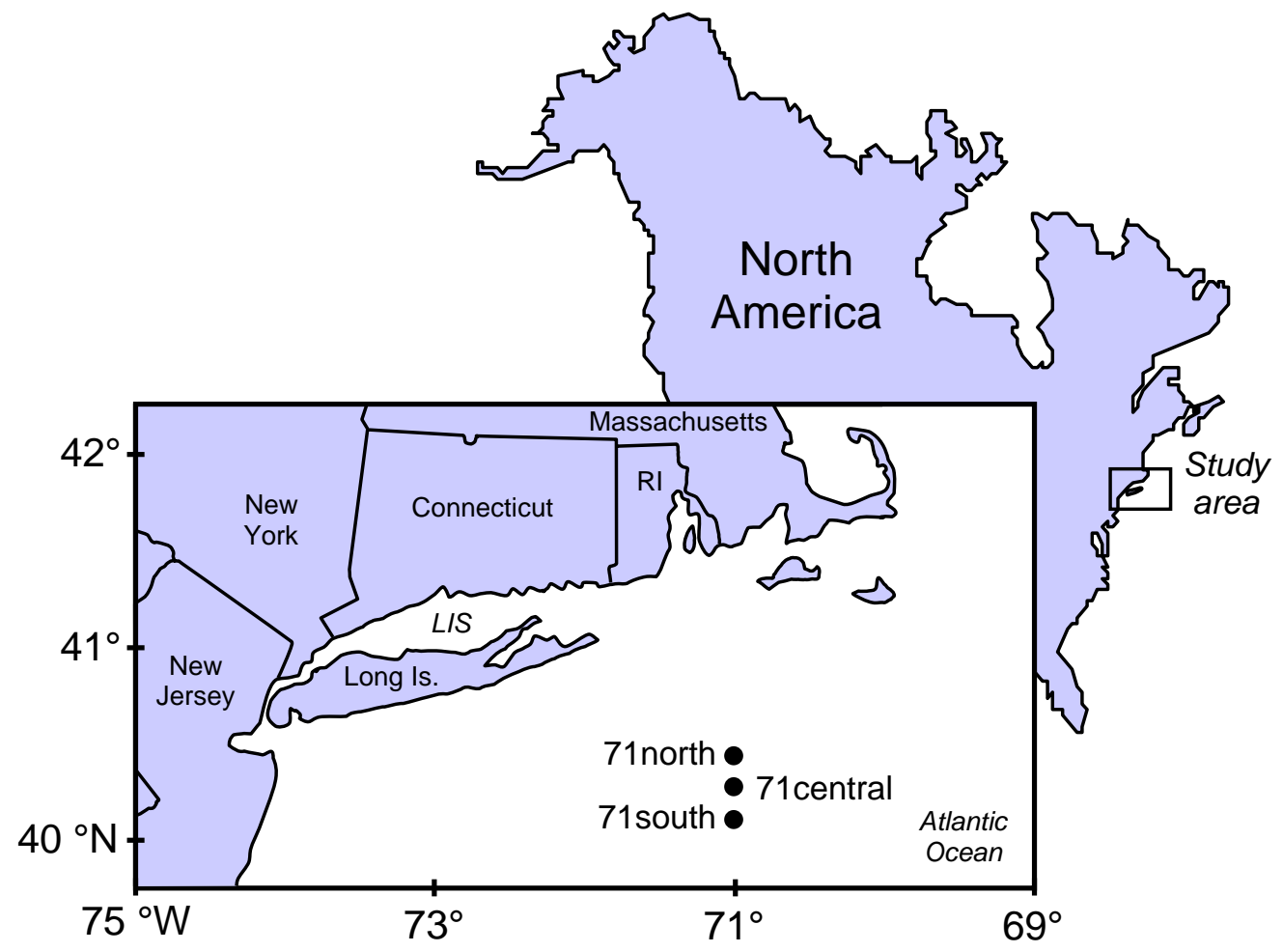


Figure 2. Hammerschmidt \& Fitzgerald

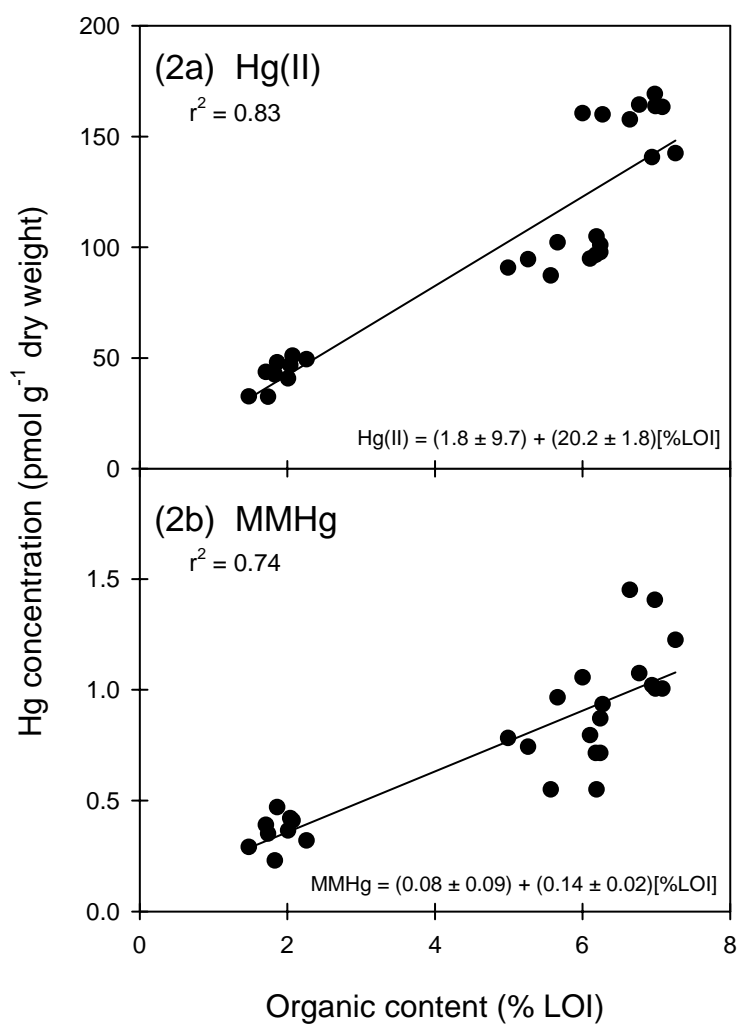


Figure 3. Hammerschmidt \& Fitzgerald

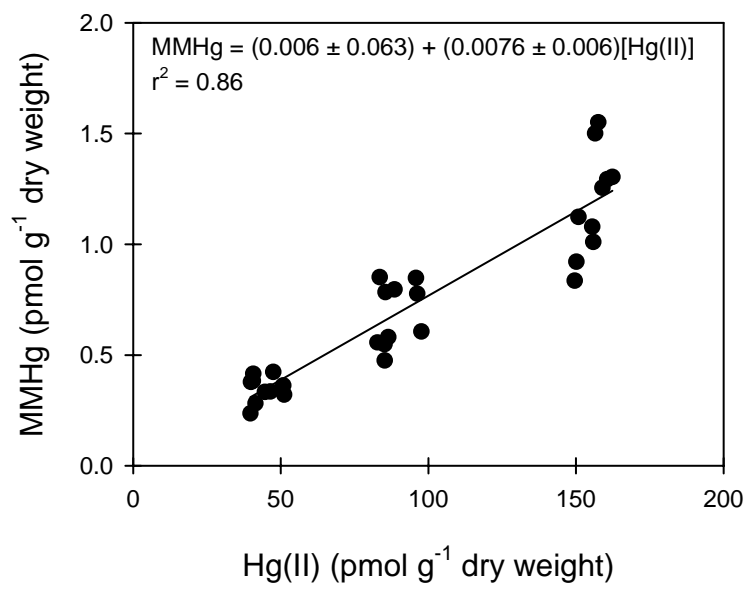


Figure 4. Hammerschmidt \& Fitzgerald

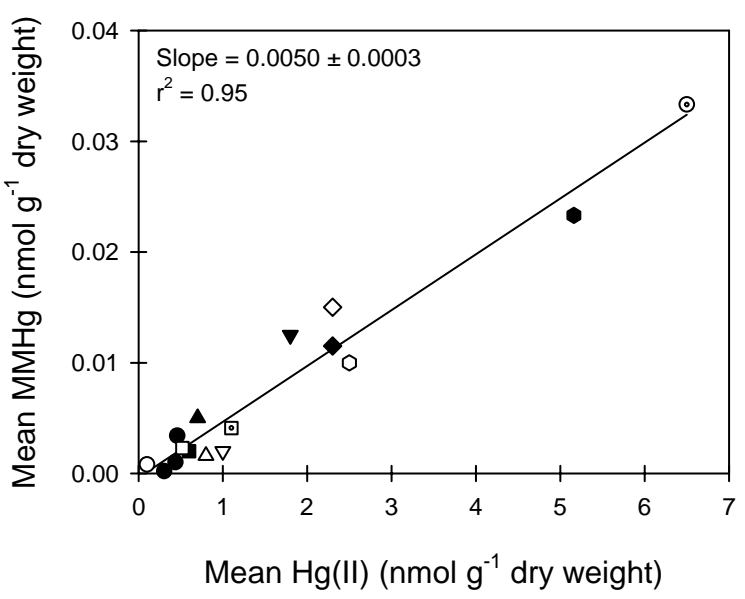


Figure 5. Hammerschmidt \& Fitzgerald

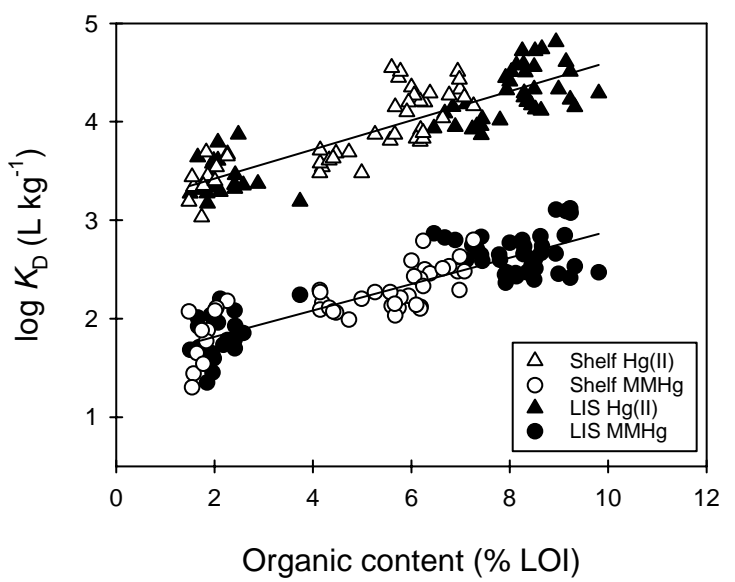


Figure 6. Hammerschmidt \& Fitzgerald

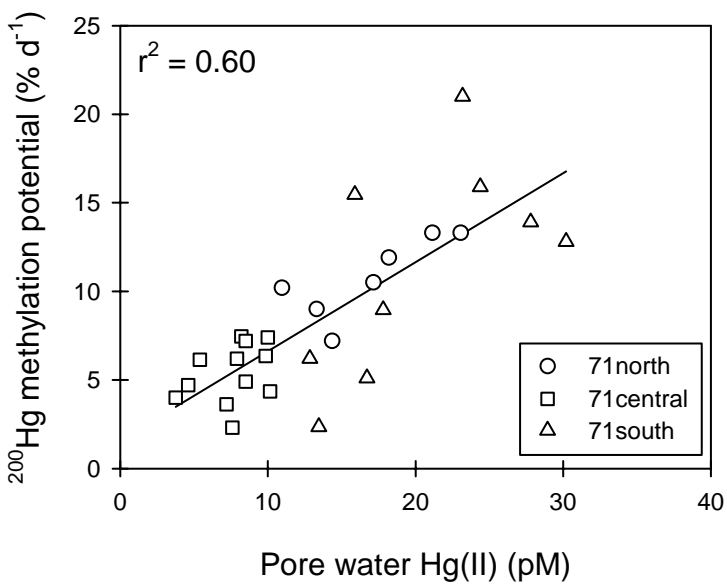


Figure 7. Hammerschmidt \& Fitzgerald

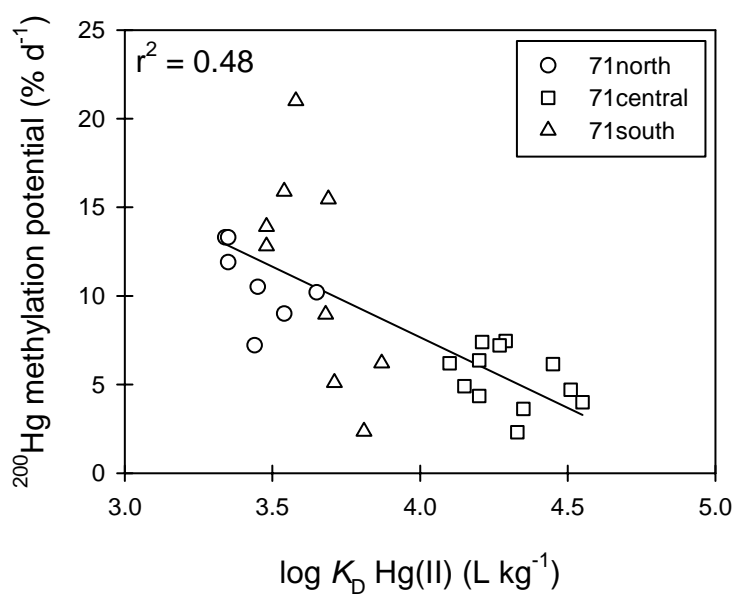


Figure 8. Hammerschmidt \& Fitzgerald
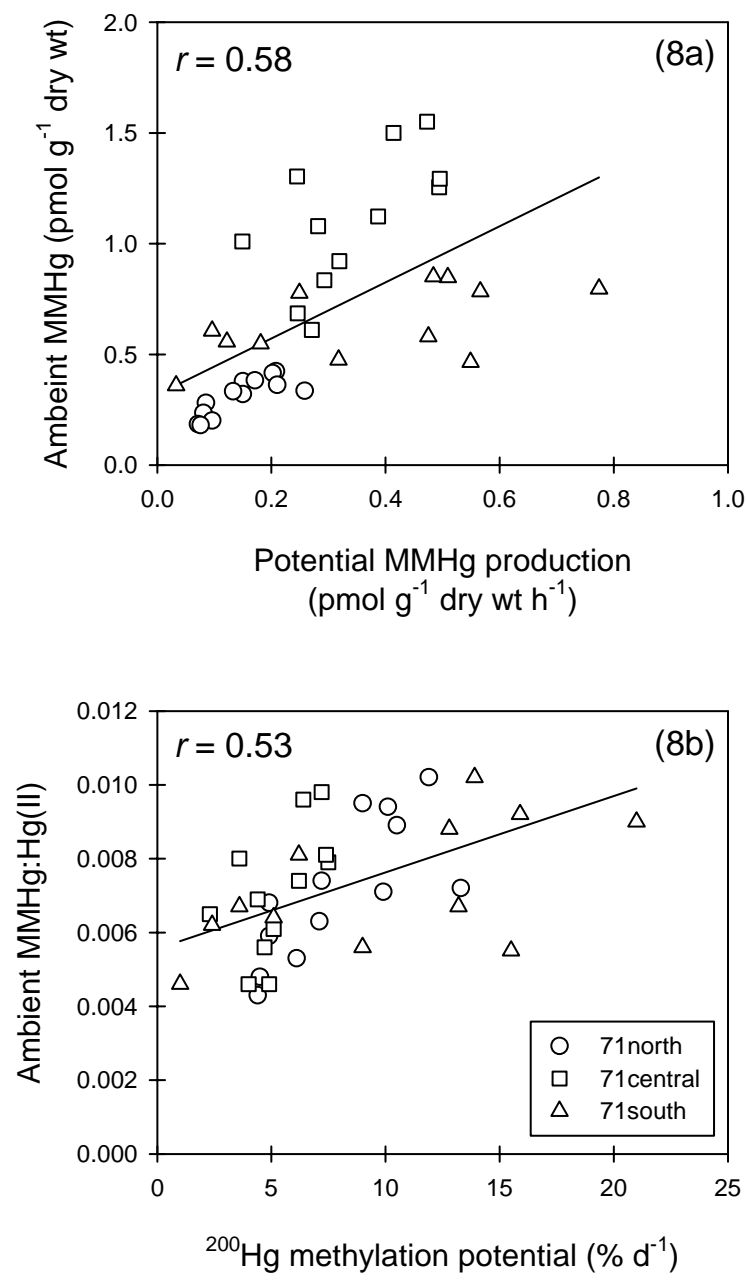
Figure 9. Hammerschmidt \& Fitzgerald

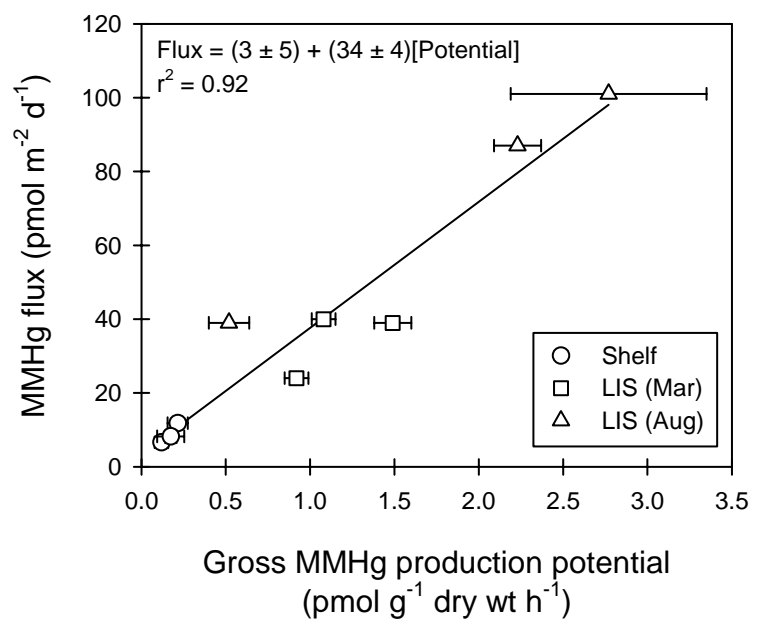


Figure 10. Hammerschmidt \& Fitzgerald

(a) 71north
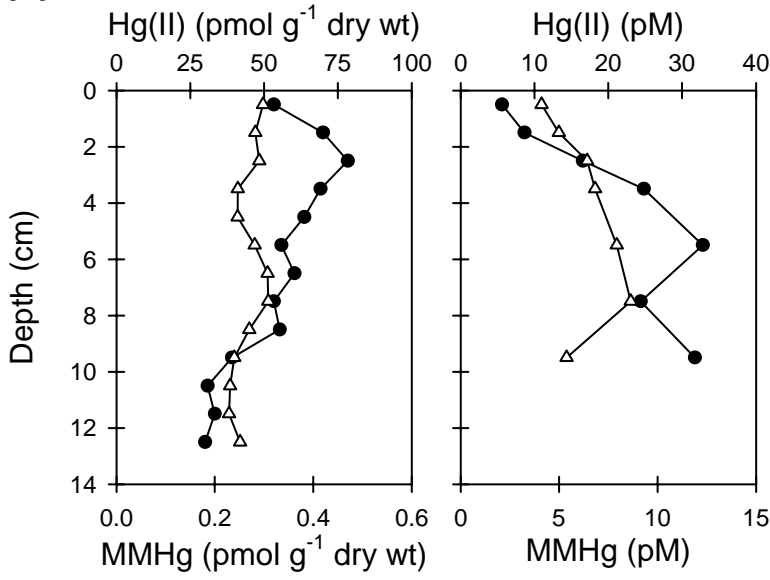

(b) 71central

$\mathrm{Hg}(\mathrm{II})$ (pmol g ${ }^{-1}$ dry wt)
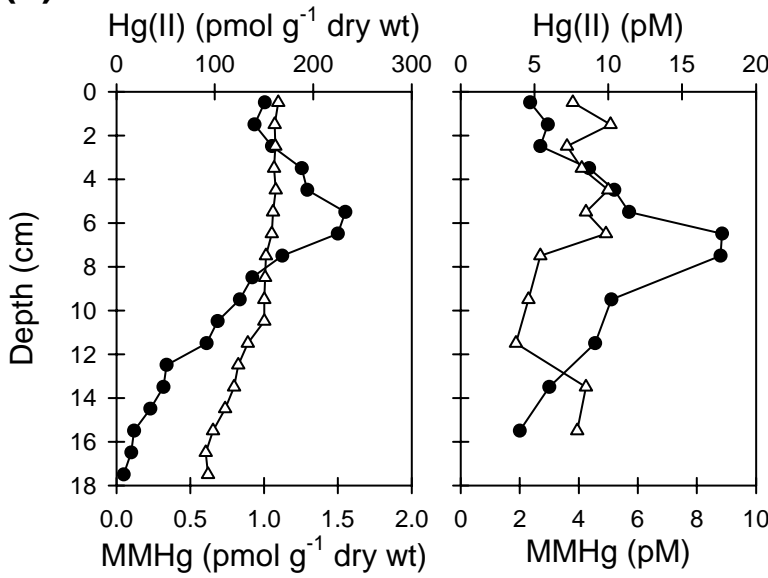

(c) 71south

$\mathrm{Hg}(\mathrm{II})$ (pmol g ${ }^{-1}$ dry wt)

$\mathrm{Hg}(\mathrm{II})$ (pM)

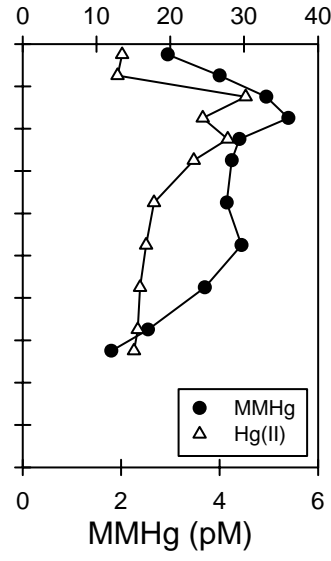

AVS $\left(\mu \mathrm{mol} \mathrm{kg}{ }^{-1}\right)$

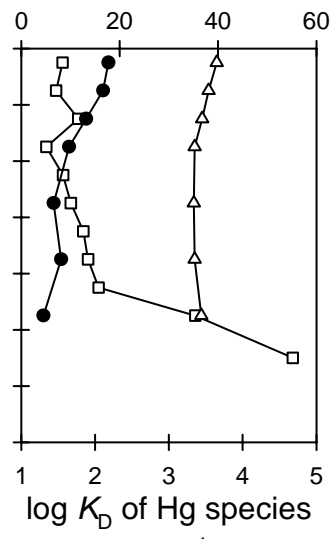

$\left(\mathrm{L} \mathrm{kg}^{-1}\right)$

AVS $\left(\mu \mathrm{mol} \mathrm{kg}{ }^{-1}\right)$

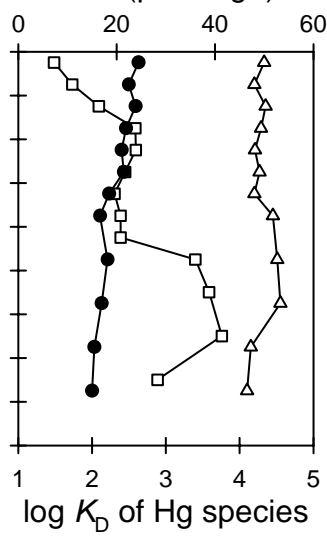

$\left(\mathrm{L} \mathrm{kg}^{-1}\right)$

AVS $\left(\mu \mathrm{mol} \mathrm{kg}{ }^{-1}\right)$

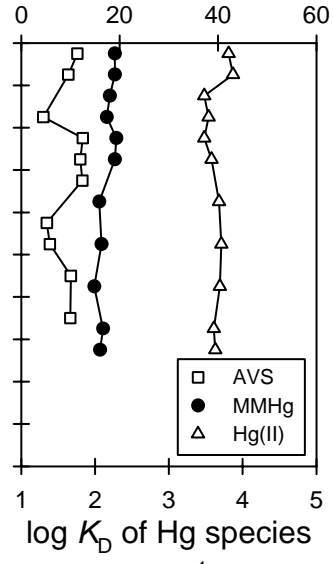

$\left(\mathrm{L} \mathrm{kg}^{-1}\right)$
Bioturbation index
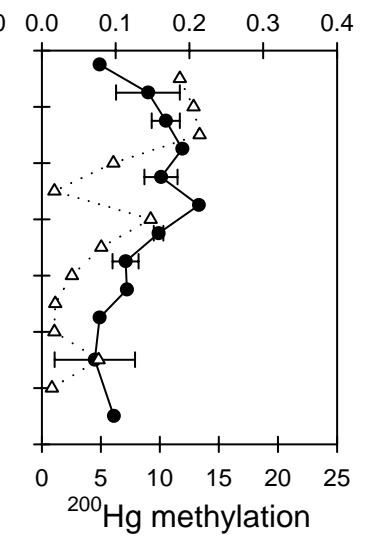

$\left(\% \mathrm{~d}^{-1}\right)$

Bioturbation index

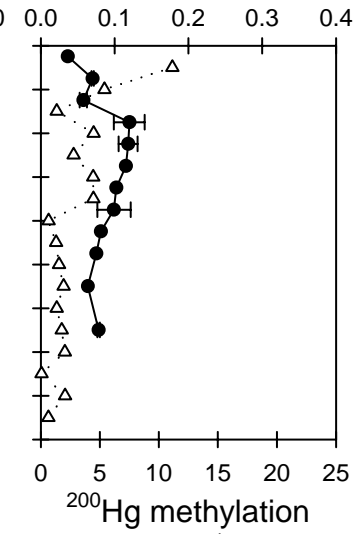

$\left(\% d^{-1}\right)$

Bioturbation index

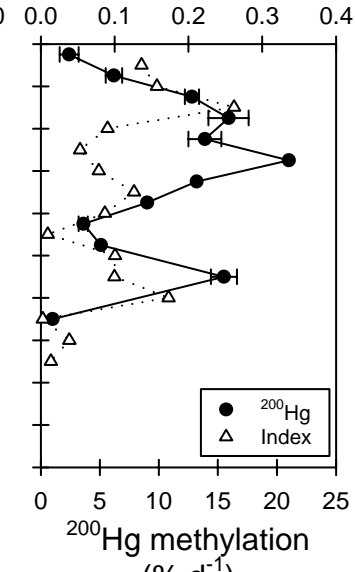


Figure 11. Hammerschmidt \& Fitzgerald

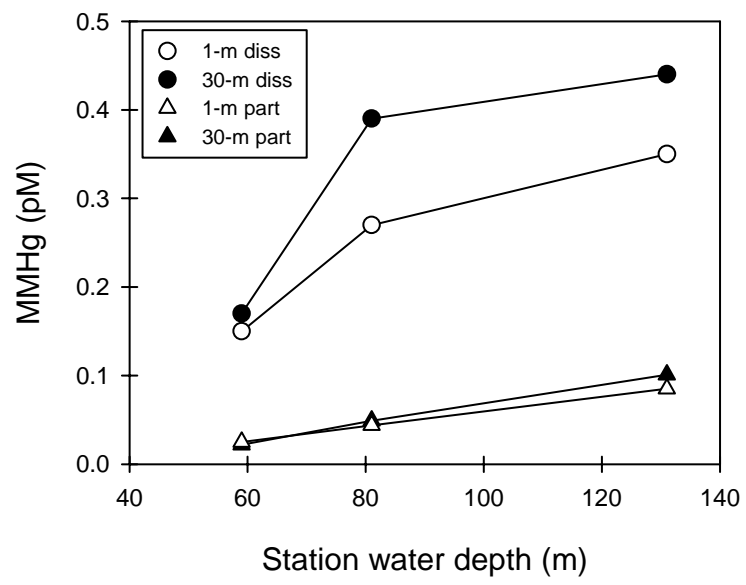

